\title{
Professional Desires and Career Decisions: Effects of Professional Interests, Role Models, and Internship in Lower Secondary School
}

\author{
Markus P. Neuenschwander*1, Jan Hofmann ${ }^{1}$, Andreas Jüttler ${ }^{2}$, \\ and Stephan Schumann ${ }^{2}$ \\ ${ }^{1}$ University of Applied Sciences and Arts Northwestern Switzerland, Center for Learning and \\ Socialization, Obere Sternengasse 7, CH-4502 Solothurn, Switzerland \\ ${ }^{2}$ Universtity of Konstanz, Department of Economics, Chair of Business and Economic \\ Education II, Universitätsstrasse 10, 78465 Konstanz, Germany
}

Received: 09.05.2018; Accepted: 24.08.2018; Published: 22.11.2018

\begin{abstract}
Context: Following the social cognitive career theory of Lent, Brown, and Hackett (1994), the current study examines the effect of role models' professions and practical internship experiences on the choice of professional environment independent of professional interests. Embedded in the Swiss context with its strong vocational training system, the paper outlines to what extent the desired professional environment is realized in the chosen apprenticeship two years later and how this realization can be predicted. The theoretical model proposes that students form direct professional experiences during their first internship(s). If those experiences are positive, students choose an apprenticeship in the same professional environment. Students have indirect (vicarious) professional experiences through their role models. If those experiences are positive, students choose an apprenticeship in the role model's professional environment. The study examined whether, independent of professional interests, direct experiences in internships and indirect experiences through role models' professions predict the realization of a desired professional environment in an apprenticeship.
\end{abstract}

${ }^{*}$ Corresponding author: markus.neuenschwander@fhnw.ch

ISSN: 2197-8646

http://www.ijrvet.net 
Method: The longitudinal sample consists of $\mathrm{N}=348$ seventh- and ninth-grade students from four German-speaking Swiss cantons. Professional interests and environments were measured using standardized questionnaires. The professional environments of the desired professions, the chosen apprenticeships, the role model's professions, and the internship's professions were coded using Holland's (1997) interest types: realistic, investigative, artistic, social, enterprising, and conventional (RIASEC).

Results: In $53 \%$ of the cases, students chose an apprenticeship in the professional environment they desired. In $53 \%$ of the cases, the chosen professional environment corresponded with the professional environment of the student's two most important role models. In $39 \%$ of the cases, those role models were their parents. By means of logistic regression analyses, we can show that role models' professional environments and the professional environment of the first internship influenced the realization of the desired professional environment at the end of lower secondary school, independent of the effect of the individuals' interests.

Conclusions: Results show that direct professional experiences in internships and indirect experiences of role models influence the realization of the desired professional environment, independent of professional interests. In a contextual approach, career counselling should include the role model's profession and how it corresponds with the client's interests and professional desires. Moreover, role models, especially parents, have a responsibility to reflect on how their goals influence students' career choice processes.

Keywords: VET, Vocational Education and Training, Career Decision, Professional Role Model, Internship, Professional Interest

\section{Theory}

In secondary education, students typically have to make first career choices to prepare for lifelong professional development. In Switzerland, about two-thirds of students choose an apprenticeship after compulsory school (Babel \& Laganà, 2016). Prior studies examined the determinants of the choice between an academic track (via high school) and a vocational track (via vocational education and training [VET]; Neuenschwander \& Malti, 2009; Neuenschwander, Fräulin, Schumann, \& Jüttler, in press) and of the fit between students' needs and school contexts (Neuenschwander, 2011). However, little knowledge exists about how students choose a professional environment (content or professional field) in their career decision processes. Lent, Brown, and Hackett (1994) proposed the social cognitive model of career choice. Career choice is predicted to some extent by students' professional interests, professional desires, role models' professions, and career activities (e.g., internships [Schnupperlehre円).

\footnotetext{
${ }^{1}$ In the Swiss context, internships are 3- to 5-day apprenticeships where students in lower secondary education work in a company. Internships help students learn more about professions. Companies evaluate students in internships to help them decide whether they want to hire students as apprentices.
} 
In this study ${ }^{2}$, we test a part of the model of Lent et al. (1994), and we consider the following questions:

1. To what extent do the desired profession and the chosen profession correspond with the professional interests, role models' professions, and profession of the first internship?

2. How often do students choose an apprenticeship in the profession they have desired to?

3. To what extent can the realization of the professional desire be predicted by professional interests, role models' professions, and profession of the first internship?

\subsection{Career Decision Model}

Lent et al. (1994) assumed that career decisions result from professional goals that correspond with professional interests and that are explored in career activities. Career decisions also result from influences of reference persons in the proximal context (role models such as parents, relatives, neighbours and others). Many aspects of the model were tested in various professional domains and for various groups, such as genders and migrants (meta-analysis from Lent, Sheu, Miller, Cusick, Penn, \& Truong, 2018).

In the social cognitive career choice model, professional desire is a key component of professional goals (Lent et al., 1994). Studies showed that educational attainment expectations predict the probability of college enrolment (Eccles, Vida, \& Barber, 2004). However, little research investigated whether early-desired professional environments are realized in apprenticeships (Tomasik, Hardy, Haase, \& Heckhausen, 2009). We understand professional desire as a rough preselection from many possible professional environments. It serves as a point of reference to evaluate future professional options. In line with Lent et al. (1994), we assume that professional desires tend to be realized. Thus, students choose a profession in VET that corresponds with their professional desires.

\subsection{Professional Interests, Role Models, and Internships}

The social cognitive career choice model explains the change of profession between the professional desire and the chosen apprenticeship. Within the model, we focus on the effects of professional interests, role models' professions, and profession of first internship on the realization of the professional desire. The model proposes that these three variables directly explain the conditions under which professional desires are realized in upper secondary education.

\footnotetext{
${ }^{2}$ This study is part of the WiSel II project that was funded by the Swiss National Science Foundation (No 100013_134594/1) and by the State Secretariat for Education, Research and Innovation (SERI 1315000504).
} 
Professional Interests

Professional interests predict professional desires and the apprenticeship's profession (Bergmann \& Eder, 2005; Lüdtke \& Trautwein, 2004; Walsh, 1999). The framework of the social cognitive career choice model assumes that self-efficacy and outcome expectations affect professional interests that in turn affect chosen goals (Sheu, Lent, Brown, Miller, Hennessy, \& Duffy, 2010) and career decisions. Professional interests are defined as the extent to which an individual likes a particular activity, academic subject, college major, or profession (Sheu et al., 2010). Students are interested in several professional environments. A person's most distinctive type of professional interest prominently steers his or her choice of professional environment. The type of interest in a specific environment predicts the professional desire and the realization of the desired profession.

In line with Holland's model, we hypothesize a high positive correspondence between the person's type of interest and the desired professional environment (Hypothesis 1a), as well as of the chosen apprenticeship (Hypothesis 1b). We also hypothesize that the correspondence between the person's type of interest and the professional environment of the chosen apprenticeship predict the probability that the desired professional environment corresponds with the chosen professional environment (Hypothesis 1c).

\section{Role Models}

The model of Lent et al. (1994) assumes that role models influence students' professional desires and career choices. Because of their holistic character, role models serve as examples of successful professional life careers that are worth copying (Makarova \& Herzog, 2014). Most students between the ages of 10 and 14 report having a role model (Zinnecker, Behnken, Maschke, \& Stecher, 2003). If students have role models, they most often are relatives like parents, uncles and aunts, or neighbours (Zinnecker, 2003). Role models exemplify professions that students become aware of, start thinking about, and imitate (Bandura, 1977). Students have indirect experiences by observing their role models and listening to their stories about their professions. Typically, students have close relationships with their role models and internalize their interests. Role models who present positive pictures of their professions make their professions attractive for the students (indirect experience). If the indirect experience is positive, the student chooses an apprenticeship in the role model's professional environment. Thus, role models' professional environments influence students' desired professional environments and their choice of professional environment in their apprenticeship.

We hypothesize a correspondence between the role model's professional environment and the student's desired professional environment (Hypothesis 2a), as well as that of the chosen apprenticeship (Hypothesis $2 \mathrm{~b}$ ). We also hypothesize that the correspondence between the role model's professional environment and the professional environment of the chosen apprenticeship predicts the probability that the desired professional environment corresponds with the chosen professional environment (Hypothesis 2c).

\section{Internships}

Moreover, Lent et al. (1994) proposed that professional desires are explored through internship activities. Students reported that their internship experiences strongly influ- 
ence their career choices (Beinke, 2013; Neuenschwander \& Schaffner, 2010). Students choose internships that correspond with their professional desires. According to Lent et al. (1994), in internships, students form direct professional experiences and explore their desired professions. If students decide to complete an internship in the desired profession and if they have positive experiences in this internship, they will likely choose an apprenticeship in the same professional environment. Occasionally, students do not like the internship, and they find new professional options in the same or another professional environment (Beinke, Richter, \& Schuld, 1996). Thus, the internship allows students to test their hypotheses that a desired profession fits with their interests and competencies. If the students like the internship and get positive feedback, they try to get an apprenticeship in that professional environment. If the students do not like the internship and/or get negative feedback, they look for other professional environments that fit with their interest and competencies.

We hypothesize a high correspondence of the professional environment of the first internship with (Hypothesis 3a) the desired professional environment and (Hypothesis $3 \mathrm{~b})$ the chosen professional environment. We also hypothesize that the correspondence between the professional environment of the first internship and the professional environment of the chosen apprenticeship predicts the probability that the desired professional environment corresponds with the chosen professional environment (Hypothesis 3c).

\subsection{Types of Interest and Professional Environments}

Holland (1997) proposed a person-environment-fit model: Students choose careers in professional environments that fit their personalities. The model assumes that people prefer professional environments that correspond with the types of the professional interest. The more precisely the interest corresponds with the professional environment, the higher are job satisfaction, stability, and performance (Nauta, 2010). Holland (1997) distinguished the RIASEC interest types, a constellation of professional interests, preferred activities, beliefs, and abilities (Nauta, 2010). Because no person corresponds only to one type, the three most dominant RIASEC types (expressed with a three-letter code) are typically used to describe a person's professional interest pattern (Nauta, 2010). The professional environment that students are most interested in is coded with the first letter, so this first letter of the three RIASEC codes is most characteristic. Likewise, work environments can be categorized by the RIASEC codes. Again, the first code is the most important one. We use the first letter of the RIASEC model to categorize the person's type of interest and the professional environments.

Prior research showed that gender influences the choice of professional environments (Hirschi, 2009). The gender gap with male dominance in the fields of science, technology, engineering, and mathematics (the so-called STEM subjects) has been well documented in most OECD countries (Jarman, Blackburn, \& Racko, 2012). Makarova, Aeschlimann, and Herzog (2016) assumed gender-typed pathways because of gender stereotypes and gender roles. While males are most interested in realistic and investigative contexts, females prefer social, artistic, and slightly less distinctively enterprising environments. Both genders are equally interested in the conventional environment (Hirschi, 2009). In 
2006 , the majority $(77.2 \%)$ of male apprentices in Switzerland learned a profession in a realistic environment, and about $17.7 \%$ took an apprenticeship in a conventional environment. Most female apprentices chose a conventional environment (40.7\%), with the second-most female apprentices in social environments (24.8\%; Hirschi, 2009). Because of the strong gender effects on the choice of professional environment, we will control for gender while testing the hypotheses.

\subsection{The Swiss Context}

This study was conducted in the Swiss German-speaking cantons Aargau, Basel-Landschaft, Berne, and Lucerne. Depending on the canton, the decision of gymnasium enrolment has to be made in eighth or ninth grade (in the canton of Lucerne, students also can choose to attend a long-term gymnasium starting in seventh grade). All students leave compulsory school after ninth grade (at about age 16). The various upper secondary education courses in Switzerland can be grouped into two main pathways: gymnasium and upper secondary specialized school (academic track) and VET (dual or full-time vocational school, vocational track). Within the vocational track, students can acquire a hybrid qualification (Deißinger, Aff, Fuller, \& Helms Jørgensen, 2012): The Federal Vocational Baccalaureate, which provides access to tertiary education, can be attained while working or after basic vocational training.

In the Swiss vocational track, more than 230 apprenticeships exist with various demands. The apprenticeships can be grouped into 32 professional fields (Federal Office for Statistics, 2017). The most popular professional field is business and administration. About $21 \%$ of the students (women: $30 \%$ ) who decide to start an apprenticeship choose this field. Professions with the highest amount of apprentices are wholesale and retail (11\%; women: 14\%), building industry (9\%; women: 1\%), and nursing and obstetrics (6\%; women: 13\%). Examples of least chosen professions are technologies of environment protection, music and dramatic arts, and sports (all $<1 \%$ ).

Students have to choose an apprenticeship in lower secondary education. They explore their interests and competencies, collect information about the apprenticeship system and complete internships. All students get professional support from classroom teachers to find and apply for an apprenticeship in the beginning of ninth grade. Students can ask for help from career counsellors in school or professional centres. Students indicate that their parents are important supporters in their vocational choice processes (Herzog, Neuenschwander, \& Wannack, 2006). Parents informally motivate and support their children to find a profession and apply for apprenticeships. According to an analysis of Swiss population statistics (Babel \& Laganà, 2016), after ninth grade, $48 \%$ of compulsory school graduates entered vocational training in 2012, $23 \%$ started gymnasium, and $4 \%$ went directly to an upper secondary specialized school. The remaining quarter of students attended a so-called bridge year after the ninth grade, went to work unskilled, repeated a school year, or took part in short-term activities (e.g., stay abroad). Women were more likely to enter gymnasium (27\%; men: 20\%; Babel \& Laganà, 2016), and men were more likely to enter vocational training (57\%; women: 38\%; Babel \& Laganà, 2016). Our analysis focused on students who entered VET after lower secondary education. 


\section{Method}

\subsection{Sample}

The analyses are based on data from the Swiss longitudinal study "Effects of Tracking". A class-wise sampling procedure in four Swiss cantons was carried out. The analyses referred to a sample of seventh- and ninth-grade students. The seventh-grade sample consisted of 1,515 students (mean age: 13 years; female: 48.0\%). From those students, 698 participated in the study again in the ninth grade (response rate: 44.3\%). For the variables that we used in this study, no significant differences existed between those who only participated in the seventh grade and those who participated in the seventh and ninth grades: professional environment of desired profession, $\chi^{2}(5)=3.01, \mathrm{p}>0.05$, $\mathrm{n}=943$; professional environment of first role model's profession, $\chi^{2}(5)=8.42, \mathrm{p}>0.05$, $\mathrm{n}=770$; professional environment of second role model's profession, $\chi^{2}(5)=5.51$, $\mathrm{p}>0.05, \mathrm{n}=535$. Because type of professional interest, professional environment of first internship, and professional environment of chosen apprenticeship were surveyed only in ninth-grade classes, between-survey selection effects could not be tested. In this study, we used the data from all 348 students who participated in the study in the seventh and ninth grades and reported that they were working in an apprenticeship $(\mathrm{n}=343)$ or were unskilled $(\mathrm{n}=5)$ after ninth grade (female: $38 \%$, mean age in ninth grade: 15.9 years).

\subsection{Instruments and Variables}

The students answered standardized questionnaires in their classrooms (seventh grade: paper and pencil, ninth grade: online). The survey was administered by trained members of the research team in seventh-grade classes and by the teacher in ninth-grade classes. Including instructions, 90 minutes were made available to the participants to fill out the questionnaires. After 45 minutes, participants had a break of between five and fifteen minutes. Students who did not complete the questionnaire received the opportunity to continue working on it but only at their own request and in consultation with their teacher. Students whose parents had consented to their participation but who were absent did not participate in the seventh-grade survey. In ninth-grade classes, they were asked to fill out the questionnaire at home.

To examine the hypotheses, several constructs were used:

1. Seventh-grade students were asked to write down their desired professions in an open format. If multiple professions were mentioned, the first profession was chosen for the analyses.

2. Seventh-grade students were asked to write down the professions of their two most important role models. Again, if multiple professions were mentioned, the first profession was chosen for the analyses.

3. In ninth-grade classes, we asked for the profession of the first internship in lower secondary school. 
4. Students' professional interests were obtained in ninth-grade classes using the Allgemeinen Interessen-Struktur-Test revision (AIST-R) [General Interest Structure Test - revised] developed by Bergmann and Eder (2005). The test measured six factors of interests with five items, based on Holland's (1973) model. All 30 items were measured with a 6-point Likert scale. The six-factor solution of the factor analysis explained $61.6 \%$ of the variance. The highest value of the six factors indicated each student's type of interest (Hirschi, 2009; Kirsten, 2007). Table 1 shows the statistics for the six factors of professional interest.

Table 1: Six Factors of Professional Interest

\begin{tabular}{lcccc}
\hline Factor & $\mathrm{N}$ & $\mathrm{M}$ & $\mathrm{SD}$ & $\alpha$ \\
\hline Realistic & 2220 & 2.45 & 0.98 & 0.76 \\
Investigative & 2207 & 2.54 & 0.99 & 0.81 \\
Artistic & 2203 & 2.61 & 0.92 & 0.73 \\
Social & 2217 & 2.84 & 1.07 & 0.82 \\
Enterprising & 2200 & 2.71 & 0.96 & 0.79 \\
Conventional & 2169 & 2.36 & 0.91 & 0.82 \\
\hline
\end{tabular}

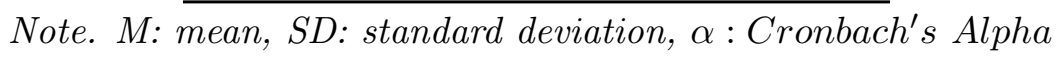

5. At the end of ninth grade, the teachers were asked to indicate the post-compulsory education of each of their students. The students were asked to write down their post-compulsory education in their survey, as well. Students' chosen apprenticeships after ninth grade was derived from the information provided by the teachers. If the teacher's information was missing, the student's information was used. The teachers typically know well what transition their students will realise.

All professions (desired profession, profession of chosen apprenticeship, professions of two role models, profession of first internship) were categorized. Professions were first coded according to the profession database provided by the Federal Statistical Office of Switzerland (FSO code). Then, according to these FSO codes, professions were categorized into professional environments using the profession register provided by EXPLORIX (Jörin, Stoll, Bergmann, \& Eder, 2003). This profession register is based on Holland's RIASEC coding system. Professions that did not have a code in EXPLORIX were coded by two trained raters, who assigned three RIASEC letters to the FSO codes (consent-based). The categorization of similar professions by EXPLORIX was used as a point of reference in the manual assignment process. Although three letters of the RIASEC coding system were assigned to each FSO code, following the common theoretical strategy (Nauta, 2010), only the first letter of the RIASEC coding system was used to categorize the professions into professional environments.

The realization of the desired professional environment was operationalized as a dummy coded variable by matching the professional environment of the desired profession with 
the professional environment of the chosen apprenticeship $(0=$ no match; $1=$ match, no response: $20.4 \%$ ). It serves as the dependent variable in logistic regression analyses. To conduct the logistic regression analyses, all independent variables were also coded as dummy variables: (a) The professional interest was operationalized by matching the professional interest type with the professional environment of the chosen apprenticeship $(0=$ no match, $1=$ match; no response: $19.8 \%)$. (b) The role model's influence on realization of the desired professional environment was measured by matching the professional environments of the two most important role models' professions with the professional environment of the student's chosen apprenticeship $(0=$ no match, $1=$ match $)$. In the case of a match, at least one of the professional environments of the role model's profession had to correspond with the professional environment of the student's chosen apprenticeship (no response: 35.6\%). (c) The first internship's influence was measured by matching the professional environment of the first internship's profession with the professional environment of the chosen apprenticeship $(0=$ no match, $1=$ match; no response: $9.2 \%)$.

\section{Results}

\subsection{Descriptors}

In the Swiss apprenticeship system, the number of professions per professional environment varied between the six RIASEC codes (R: $65.4 \%$, I: $1.8 \%, \mathrm{~A}: 10.1 \%$, S: $7.8 \%$, E: $4.6 \%$, C: $10.1 \%$ ). In 2006 , the ratio between the six RIASEC types in all available apprenticeships was similar, but slightly more available apprenticeships were in the conventional environment (R: 53.6\%, I. 0.9\%, A: 5.1\%, S: 10.6\%, E: 3.1\%, C: 26.8\%; Hirschi, 2009). We first present the frequencies of the types of desired professional environments in seventh-grade responses in combination with the chosen professional environments after ninth grade (Table 2). Students with professional desires in realistic, social, and conventional professional environments often realized their desired professional environments in their apprenticeships after ninth grade (R: $74.8 \%$, S: $53.1 \%$, C: $50.0 \%$ ). However, the students' chosen professional environments changed after ninth grade, when they desired a profession in the investigative, artistic, or enterprising field in seventh grade because of rare opportunities. They often changed to a realistic or conventional type of professional environment when they started their apprenticeships. Overall, most of the chosen apprenticeships were located in realistic and conventional professional environments (R: $51.8 \%$, C: $39.3 \%$ ). 
Table 2: Correspondences between Types of Professional Environments of Desired and Chosen Apprenticeship after 9th Grade

Chosen apprenticeship after 9th grade

\begin{tabular}{|c|c|c|c|c|c|c|c|c|}
\hline \multirow{17}{*}{ 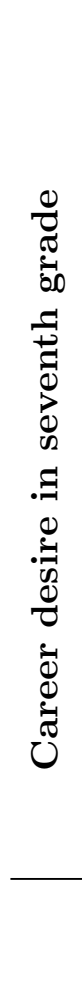 } & & $\mathrm{R}$ & I & A & $\mathrm{S}$ & $\mathrm{E}$ & $\mathrm{C}$ & sum \\
\hline & & 98 & 0 & 2 & 5 & 1 & 25 & 131 \\
\hline & $\mathrm{R}$ & $74.8 \%$ & $0.0 \%$ & $1.5 \%$ & $3.8 \%$ & $0.8 \%$ & $19.1 \%$ & $100 \%$ \\
\hline & $\mathrm{I}$ & 7 & 0 & 0 & 0 & 0 & 2 & 9 \\
\hline & 1 & $77.8 \%$ & $0.0 \%$ & $0.0 \%$ & $0.0 \%$ & $0.0 \%$ & $22.2 \%$ & $100 \%$ \\
\hline & A & 13 & 0 & 3 & 6 & 0 & 11 & 33 \\
\hline & & $39.2 \%$ & $0.0 \%$ & $9.1 \%$ & $18.2 \%$ & $0.0 \%$ & $33.3 \%$ & $100 \%$ \\
\hline & $\mathrm{S}$ & 8 & 0 & 3 & 26 & 0 & 12 & 49 \\
\hline & N & $16.3 \%$ & $0.0 \%$ & $6.1 \%$ & $53.1 \%$ & $0.0 \%$ & $24.5 \%$ & $100 \%$ \\
\hline & $F$ & 10 & 0 & 0 & 2 & 3 & 12 & 27 \\
\hline & $\mathrm{L}$ & $37.0 \%$ & $0.0 \%$ & $0.0 \%$ & $7.4 \%$ & $11.1 \%$ & $44.4 \%$ & $100 \%$ \\
\hline & $C$ & 11 & 0 & 1 & 1 & 1 & 14 & 28 \\
\hline & & $39.3 \%$ & $0.0 \%$ & $3.6 \%$ & $3.6 \%$ & $3.6 \%$ & $50.0 \%$ & $100 \%$ \\
\hline & & 28 & 1 & 1 & 6 & 2 & 23 & 61 \\
\hline & n.a. & $45.9 \%$ & $1.6 \%$ & $1.6 \%$ & $9.8 \%$ & $3.3 \%$ & $37.7 \%$ & $100 \%$ \\
\hline & & 175 & 1 & 10 & 46 & 7 & 99 & 338 \\
\hline & sum & $51.8 \%$ & $0.3 \%$ & $3.0 \%$ & $13.6 \%$ & $2.1 \%$ & $39.3 \%$ & $100 \%$ \\
\hline
\end{tabular}

Note. R: Realistic, I: Investigative, A: Artistic, S: Social, E: Enterprising,

C: Conventional, n.a.: missing value, Frequencies and percentages, $\chi^{2}=148.6$, $\mathrm{df}=36$,

$$
\mathrm{p}<.001 ;
$$

We now present the frequencies of the role models mentioned as first or second entries in the seventh-grade survey. Among the 348 seventh- and ninth-grade students who participated in the study and reported that they were working (apprenticeship or unskilled work) after ninth grade, 261 (75\%) named at least one professional role model (Table 3). The persons are presented for the first and second role model and in total. The table shows that students' fathers are the most common role model for most of the students. "Mother" and "male famous/public person" were mentioned second and third as primary role models. Along with "father," "mother," "male famous/public person," and "other male person," "uncle" and "aunt" were named relatively often as second role models. Overall, about $39 \%$ of the students listed their father or mother as their primary or secondary role model. In $32 \%$ of the cases, other male or female relatives were indicated as role models. These results are consistent with other studies in this field, which report that parents and relatives are mentioned the most as role models (Makarova \& Herzog, 2014; Maschetzke, 2009; Zinnecker, et al., 2003; Zinnecker \& Silbereisen, 1996). Famous public persons $(9 \%)$ were rarely mentioned. Table 3 illustrates the types of persons that serve as students' role models. 
Table 3: First and Second Role Model

\begin{tabular}{|c|c|c|c|c|c|c|}
\hline \multirow{2}{*}{ Role model } & \multicolumn{2}{|c|}{ first entry } & \multicolumn{2}{|c|}{ second entry } & \multicolumn{2}{|c|}{ total } \\
\hline & $\mathrm{N}$ & $\%$ & $\mathrm{~N}$ & $\%$ & $\mathrm{~N}$ & $\%$ \\
\hline Father & 90 & 34.9 & 29 & 14.8 & 119 & 26.2 \\
\hline Mother & 32 & 12.4 & 26 & 13.3 & 58 & 12.8 \\
\hline Famous/public person & 22 & 8.5 & 20 & 10.2 & 42 & 9.3 \\
\hline Other male person & 16 & 6.2 & 22 & 11.2 & 38 & 8.4 \\
\hline Friend/colleague & 13 & 5 & 5 & 2.6 & 18 & 4 \\
\hline Brother & 12 & 4.7 & 8 & 4.1 & 20 & 4.4 \\
\hline Male cousin & 11 & 4.3 & 5 & 2.6 & 16 & 3.5 \\
\hline Female cousin & 10 & 3.9 & 8 & 4.1 & 18 & 4 \\
\hline Uncle & 10 & 3.9 & 12 & 6.1 & 22 & 4.8 \\
\hline Other female person & 10 & 3.9 & 8 & 4.1 & 18 & 4 \\
\hline Other male relative & 8 & 3.1 & 9 & 4.6 & 17 & 3.7 \\
\hline Sister & 7 & 2.7 & 6 & 3.1 & 13 & 2.9 \\
\hline Godmother or godfather & 7 & 2.7 & 10 & 5.1 & 17 & 3.7 \\
\hline Other female relative & 5 & 1.9 & 7 & 3.6 & 12 & 2.6 \\
\hline Aunt & 4 & 1.6 & 13 & 6.6 & 17 & 3.7 \\
\hline Grandmother or grandfather & 1 & 0.4 & 8 & 4.1 & 9 & 2 \\
\hline Total & 258 & 100 & 196 & 100 & 454 & 100 \\
\hline
\end{tabular}

Note. Frequencies and Totals. father $=$ father or stepfather or spouse of mother; mother $=$ mother or stepmother or spouse of father; friend $/$ colleague $=$ friend/colleague or friend/colleague of parents or friend/spouse of sibling

\subsection{Correspondences}

To receive more reliable values to test the hypotheses, missing data were imputed 20 times using the multiple imputation procedure in SPSS (Graham, 2009). Results in Table 4 and Table 5 were calculated using the imputed data.

Correspondences of professional environments between various professional variables were analysed (Table 4). The correspondence between the desired professional environment and the chosen apprenticeship's environment is quite high (53.2\%). This result indicates that the RIASEC codes of the desired and chosen professional environments corresponded in $53.2 \%$ of the cases. The frequency of persons whose RIASEC codes match between the desired and the chosen professional environments was significantly higher than that of the persons whose RIASEC codes do not match. The results show 
that the desired professional environment corresponds with the type of professional interest in $46 \%$ of the cases (Hypothesis 1a), with the professional environment of at least one of the role models' professions in $69 \%$ of the cases (Hypothesis $2 \mathrm{a}$ ) and with the professional environment of the first internship's profession in $56 \%$ of the cases (Hypothesis 3a). The professional environment of the chosen apprenticeship corresponds with the type of professional interest in $53 \%$ of the cases (Hypothesis 1b), with the professional environment of at least one of the role models' professions in 53\% of the cases (Hypothesis $2 \mathrm{~b}$ ) and with the professional environment of the first internship's profession in $76 \%$ of the cases (Hypothesis $3 \mathrm{~b}$ ).

Table 4: Correspondences Between Professional Environments and Types of Professional Interest in Seventh and Ninth grades

\begin{tabular}{lrrrr}
\hline & 2 & 3 & 4 & 5 \\
\hline 1 Desired profession ( ${ }^{\text {th }}$ grade) & 185 & 241 & 194 & 159 \\
& $53.2 \%$ & $69.3 \%$ & $55.7 \%$ & $45.7 \%$ \\
& & & & \\
2 Chosen apprenticeship (9 ${ }^{\text {th }}$ grade) & 183 & 265 & 186 \\
& $52.6 \%$ & $76.1 \%$ & $53.4 \%$ \\
3 Role models' professions ( & & & \\
& & 184 & 166 \\
& & $52.9 \%$ & $47.7 \%$ \\
4 Prade) & & & 178 \\
5 Type of professional interest $\left(9^{\text {th }}\right.$ grade) & & & $51.1 \%$ \\
\hline
\end{tabular}

Note. $\mathrm{N}$ total per field $=348$. Frequencies and Percentages. For all match pairs, the frequencies between matching and non-matching RIASEC codes differ significantly:

$$
\mathrm{p}<.001 .
$$

\subsection{Prediction of the Realized Transition}

Stepwise logistic regression analyses with Mplus were conducted to predict the probability of match of the RIASEC code between the desired professional environment and the chosen professional environment (Table 5), and gender effects were controlled. The effect of professional interest is significant (Model 3). The effect is reduced after inclusion of the role model's profession (Model 4). All three independent variables significantly predicted the probability that the professional environment of the professional desire would be realized in the chosen apprenticeship (Model 5; explained variance: 23.2\%). The strongest standardized effect (beta $=.30, \mathrm{p}<.001$ ) can be found for the role models' professional 
environments (H2c) (type of professional interest: beta $=.15, \mathrm{p}<.001$ [Hypothesis 1c], professional environment of first internship: beta $=.20, \mathrm{p}<.001$ [Hypothesis 3c]) after controlling for gender. Therefore, all three hypotheses regarding the realization of the desired professional environment in the apprenticeship after ninth grade (Hypothesis 1c, Hypothesis 2c, and Hypothesis 3c) were confirmed.

Table 5: Prediction of Realization of the Desired Professional Environment in Upper Secondary Apprenticeship: Stepwise Logistic Regression Analyses, Standardized Coefficients

\begin{tabular}{llllll}
\hline predictor & Model 1 & Model 2 & Model 3 & Model 4 & Model 5 \\
\hline $\begin{array}{l}\text { Type of professional interest } \\
\text { Role models' professions }\end{array}$ & & & $.24^{* * *}$ & $.19^{* *}$ & $.15^{*}$ \\
Profession of first internship & $.28^{* * *}$ & & & $.32^{* * * *}$ & $.30^{* * *}$ \\
Gender & .11 & $.14^{*}$ & $.14^{*}$ & .11 & $.20^{* *}$ \\
\hline $\mathrm{N}$ & 348 & 348 & 348 & 348 & 348 \\
$\mathrm{AIC}$ & 473 & 451 & 478 & 437 & 423 \\
$R^{2}$ & $10.5 \%$ & $15.8 \%$ & $9.1 \%$ & $19.6 \%$ & $23.2 \%$ \\
\hline
\end{tabular}

Note. ${ }^{*} \mathrm{p}<0.05,{ }^{* *} \mathrm{p}<0.01,{ }^{* * *} \mathrm{p}<0.001, \mathrm{~N}=348$

\section{Discussion}

The aim of the study was to explain how students choose professional environments at the end of lower secondary education. Our data show that a significant and high correspondence exists between role models' professional environments and the desired $(69 \%)$ and chosen $(53 \%)$ professional environments (Hypotheses $2 \mathrm{a}$ and $2 \mathrm{~b}$ confirmed). The same holds for the correspondence between the professional environment of the first internship with the desired (56\%) and the chosen (76\%) professional environments (Hypotheses $3 \mathrm{a}$ and $3 \mathrm{~b}$ confirmed). In both cases, the correspondences tended to be higher than the correspondences between a person's type of interest and the desired (46\%) and the chosen $(53 \%)$ professional environments (Hypotheses 1a and $1 \mathrm{~b}$ confirmed). In line with the model of Lent et al. (1994), the results show that the person's type of interest (Hypothesis 1c confirmed), professional environments of role models (Hypothesis 2c confirmed) and the professional environment of the first internship (Hypothesis 3c confirmed) predicted the probability that the desired professional environment of seventhgrade students corresponds with the chosen professional environment in apprenticeship two years later. Although a person's type of interest has an independent effect on the realization of the desired professional environment, it is partly mediated by the role models' professional environments and the professional environments of the first internships. Because several studies investigated the importance of interests (Tarnai \& Hartmann, 
2015), little research shows the substantial effect of role models and internships within the career choice process although it is assumed in theory (Lent et al., 1994). The social cognitive career theory (Lent et al., 1994) is suitable for explaining this process and allows for prediction of the professional environments that students choose.

It was possible to adapt the model that Lent et al. (1994) developed in the U.S. context for the case of Switzerland. Prior research examined more aspects of the model in various countries (Lent et al., 2018). With small adaptations, the model can be applied to several education systems. The results stress the importance of students' direct and indirect experiences in work environments for career decisions (Bandura, 1977). Students choose an internship in a professional environment where they learn new activities and get feedback about their competences and values. Those concrete experiences influence students' professional goals and expectations. If students get positive feedback and start an apprenticeship in the same professional environment, they have a high probability of realizing their desired professional environment. Additionally, role models offer indirect professional experiences. They offer concrete insight about professional activities. Parents are the most frequently chosen role models (39\% of the cases). If role models present a positive view of their professional environments, students tend to choose an apprenticeship in those professional environments. Results indicate that the correspondence between the role models' professions and the chosen apprenticeships predict the probability that students realize the desired professional environments in their apprenticeships.

\subsection{Limitations}

The study has several limitations. The professions were coded by the RIASEC system, which represents broad professional fields and not specific professions. The correspondences between desired profession, chosen apprenticeship, role model's profession, and internship's profession are lower when analysed on a more specific level. Coding every single profession would have over-specified the empirical model. Then, a person's type of interest and internship professions were measured in ninth grade whereas role models' professions were measured in seventh grade. The type of interest, the internship profession and the chosen apprenticeship are measured in a narrower time range than the professions of the role models and the desired apprenticeship, which is why the correspondence between type of interest and profession of the chosen apprenticeship could be enhanced. We used the type of interest as a control variable to evaluate the prediction of role models' professions and internship profession. The strengths of the effects of interest type, role models' profession, and internship profession cannot be directly compared with each other.

Future research should examine, following the model of Lent et al. (1994), how role models and internships affect students' career choice processes in various countries. Such research would show how educational system structures interact with individual career choice processes. 


\subsection{Practical Implications}

The results have implications in two perspectives: professional counselling and education. The results may help career counsellors shape their counselling methods by allowing them to take a closer look at students' role models and consider practical experiences. Counsellors should include the role models' professions and how they correspond with the client's interests and desired profession. For example, counsellors could ask students about their role models' professions and how they correspond with their interests. This contextual view is in line with recent career counselling theory (Savickas, 2012). Then counsellors should encourage students to explore their desired professions in internships. The activities in companies give a concrete picture of the professions, and students receive positive or negative feedback. This feedback helps them choose a profession in an apprenticeship or find a new, better-fitting profession. This approach encourages counsellors not only to focus on students' interests but also to include direct and indirect student experiences.

Moreover, persons who are role models for students should be aware of their responsibilities in presenting their professional experiences. Role models are responsible for reflecting their goals and how they influence students' career choice processes. Our results show that parents and relatives are the most common role models. Parents should be aware of their predestined function as professional role models and consider how they influence their offspring's career choice process, including the possibility of limiting their influence and letting students make their self-determined career decisions independent of the parents' wishes. Therefore, the role model function includes helping students form their educational perspectives, and educational players promote and hinder students' career choice processes.

\section{References}

Babel, J., \& Laganà, F. (2016). Der Übergang am Ende der obligatorischen Schule [Transition at the end of compulsory school]. Neuchâtel, Switzerland: Bundesamt für Statistik.

Bandura, A. (1977). Social Learning Theory. Englewood Cliffs, NY: Prentice-Hall.

Beinke, L. (2013). Das Betriebspraktikum als Instrument der Berufsorientierung [The internship as an instrument of vocational orientation]. In T. Brüggemann \& S. Rahn (Eds.), Berufsorientierung. Ein Lehr- und Arbeitsbuch /Vocational orientation. A text- and workbook] (pp. 262-270). Berlin, Germany: Waxmann Verlag GmbH.

Beinke, L., Richter, H., \& Schuld, E. (1996). Bedeutsamkeit der Betriebspraktika für die Berufsentscheidung [Significance of internships for career decision]. Bad Honnef, Germany: Verlag K.H. Bock.

Bergmann, C., \& Eder, F. (1992). Allgemeiner Interessen-Struktur-Test/Umwelt-StrukturTest (AIST/UST) [General Interest Structure Test / Environmental Structure Test (GIST/EST)]. Weinheim, Germany: Beltz.

Bergmann, C., \& Eder, F. (2005). AIST-R. Allgemeiner Interessen-Struktur-Test mit Umwelt-Struktur-Test (UST-R) [GIST-R. General interest structure test with environmental structure test (EST-R)]-Revision. Göttingen, Germany: Beltz Test $\mathrm{GmbH}$. 
Bundesamt für Statistik. (2017). Statistik der beruflichen Grundbildung 2016 [Vocational education and training statistics 2016]. Retrieved from https://www.bfs.admin.ch/b fs/de/home/statistiken/kataloge-datenbanken/tabellen.assetdetail.2360748.html

Deißinger, T., Aff, J., Fulla, A., \& Helms Jørgensen, C. (2012). Hybrid qualifications. Structural and political issues in the context of European VET policy. Bern, Switzerland: Peter Lang AG, Internationaler Verlag der Wissenschaften.

Eccles, J. S., Vida, M. N., \& Barber, B. (2004). The relation of early adolescents' college plans and both academic ability and task-value beliefs to subsequent college enrolment. Journal of Early Adolescence, 24(1), 63-77. doi 10.1177/0272431603260919

Graham, J. W. (2009). Missing data analysis: Making it work in the real world. Annual Review of Psychology, 60, 549-576. doi:0.1146/annurev.psych.58.110405.085530

Herzog, W., Neuenschwander, M. P., \& Wannack, E. (2006). Berufswahlprozess. Wie sich Jugendliche auf ihren Beruf vorbereiten [The occupational choice process. How adolescents prepare for their occupation]. Bern, Switzerland: Haupt.

Hirschi, A. (2009). Eine typologische Analyse des Schweizerischen Lehrstellenmarktes: Strukturelle Benachteiligung von jungen Frauen /A typological analysis of the Swiss apprenticeship market: Structural disadvantages of young women]. Schweizerische Zeitschrift für Bildungswissenschaften, 31(2), 1-18.

Holland, J. L. (1973). Making Vocational Choices. Englewood Cliffs, NJ: Prentice-Hall.

Holland, J. L. (1997). Making vocational choices. A theory of vocational personalities and work environments (3rd ed.). Odessa, FL: Psychological Assessment Resources.

Jarman, J. R., Blackburn, M., \& Racko, G. (2012). The dimensions of occupational gender segregation in industrial countries. Sociology, 46(6), 1003-1019.

Jörin, S., Stoll, F., Bergmann, C., \& Eder, F. (2003). EXPLORIX - das Werkzeug zur Berufswahl und Laufbahnplanung. Deutschsprachige Adaptation und Weiterentwicklung des Self-Directed Search (SDS) nach John Holland [EXPLORIX - the tool for career choice and career planning. German-speaking adaptation and further development of the Self-Directed Search (SDS) according to John Holland]. Bern, Switzerland: Huber.

Kirsten, B. (2007). Prädiktoren einer Studienwahlentscheidung. Die Entwicklung eines Studienwahlmodells auf Basis der Theory of Circumscription and Compromise" nach Gottfredson (1981) [Predictors of choice of academic studies. The development of a study selection model based on the "Theory of Circumscription and Compromise" by Gottfredson (1981)] (Doctoral Dissertation). Bergische Universität Wuppertal, Wuppertal.

Lent, R. W., Brown, S. D., \& Hackett, G. (1994). Toward a unifying social cognitive theory of career and academic interest, choice, and performance. Journal of Vocational Behaviour, 45(1), 79-122.

Lent, R. W., Sheu, H. B., Miller, M. J., Cusick, M. E., Penn, L. T., \& Truong, N. N. (2018). Predictors of science, technology, engineering, and mathematics choice options: A meta-analytic path analysis of the social-cognitive choice model by gender and race/ethnicity. Journal of Counseling Psychology, 65(1), 17-35.

Lüdtke, O., \& Trautwein, U. (2004). Die gymnasiale Oberstufe und psychische Ressourcen: Gewissenhaftigkeit, intellektuelle Offenheit und die Entwicklung von Berufsinter- 
essen [Gymnasium and psychological resources: conscientiousness, intellectual openness and the development of professional interests]. In O. Köller, R. Watermann, U. Trautwein \& O. Lüdtke (Eds.), Wege zur Hochschulreife in Baden-Württemberg: TOSCA - Eine Untersuchung an allgemein bildenden und beruflichen Gymnasien [Ways to higher education entrance qualification in Baden-Württemberg: TOSCA - A study at general education and vocational secondary schools] (S. 367-401). Opladen, Germany. VS Verlag für Sozialwissenschaften.

Makarova, E., Aeschlimann, B., \& Herzog, W. (2016). Why is the pipeline leaking? Empirical Research in Vocational Education and Training, 8(2), 1-18. doi:10.1186/s40461016-0027-y

Makarova, E., \& Herzog, W. (2014). Geschlechtsuntypische Berufswahlen bei jungen Frauen: Muss das Vorbild weiblich sein? [Gender-atypical career choices of young women: Must the role model be female?]. Zeitschrift für Soziologie der Erziehung und Sozialisation, 34(1), 38-54.

Maschetzke, C. (2009). Die Bedeutung der Eltern im Prozess der Berufsorientierung [The role of parents in the process of vocational orientation]. In M. Oechsle, H. Knauf, C. Maschetzke \& E. Rosowski (Eds.), Abitur und was dann? Berufsorientierung und Lebensplanung junger Frauen und Männer und der Einfluss von Schule und Eltern [Higher education, and then? Career orientation and life planning of young women and men and the influence of school and parents] (S. 181-228). Wiesbaden, Germany: Verlag für Sozialwissenschaften.

Nauta, M. M. (2010). The development, evolution, and status of Holland's theory of vocational personalities: Reflections and future directions for counselling psychology. Journal of Counseling Psychology, 57(1), 11-22. doi:10.1037/a0018213

Neuenschwander, M. P., \& Malti, T. (2009). Selektionsprozesse beim Ubergang in die Sekundarstufe I und II [Selection processes in the transition to lower and upper secondary education]. Zeitschrift für Erziehungswissenschaft, 12(2), 216-232.

Neuenschwander, M. P. (2011). Determinanten der Passungswahrnehmung nach dem Übergang in die Sekundarstufe II [Determinants of Perceived Fit after Transition to Upper Secondary Education]. Schweizerische Zeitschrift für Bildungswissenschaften, 33(3), 401-419.

Neuenschwander, M. P., \& Schaffner, N. (2010). Berufsorientierung an Schulen (Schlussbericht) [Occupational orientation in schools (final report)]. Solothurn, Switzerland: Pädagogische Hochschule FHNW.

Neuenschwander, M. P., Fräulin, J., Schumann, S., \& Jüttler, A. (in press). Gymnasium oder Berufsausbildung? Zur Vorhersage der Bildungsentscheidung in der Sekundarstufe II durch Schülerleistungen sowie Leistungserwartungen von Lehrpersonen und Eltern in der Primarschulzeit [Higher education or apprenticeship? Predicting educational decisions at upper secondary level through student performance and performance expectations of teachers and parents during primary schooling]. Zeitschrift für Soziologie der Erziehung und Sozialisation.

Savickas, M.L. (2012). Life design: A paradigm for career intervention in the 21st century. Journal of Counselling \& Development, 90(1), 13-19. 
Sheu, H.B., Lent, R. W., Brown, S. D., Miller, M. J., Hennessy, K. D., \& Duffy, R. D. (2010). Testing the choice model of social cognitive career theory across Holland themes: A meta-analytic path analysis. Journal of Vocational Behavior, 76(2), 252264.

Tarnai, C., \& Hartmann, F.G. (2015). Berufliche Interessen. Beiträge zur Theorie von J.L. Holland [Professional interests. Contributions to the theory of J.L. Holland]. Münster, Germany: Waxmann.

Tomasik, M. J., Hardy, S., Haase, C. M., \& Heckhausen, J. (2009). Adaptive adjustment of vocational aspirations among German youths during the transition from school to work. Journal of Vocational Behavior, 74(1), 38-46.

Walsh, W. B. (1999). What we know and need to know: A few comments. In M. L. Savickas \& A. R. Spokane (Eds.), Vocational Interests. Meaning, Measurement and Counselling Use (pp. 371-382). Palo Alto, CA: Davies-Black.

Zinnecker, J., \& Silbereisen, R. K. (1996). Kindheit in Deutschland. Aktueller Survey über Kinder und ihre Eltern [Childhood in Germany. Current survey on children and their parents]. Weinheim, Germany: Juventa.

Zinnecker, J., Behnken, I., Maschke, S., \& Stecher, L. (2003). Null zoff $\&$ voll busy. Die erste Jugendgeneration des neuen Jahrhunderts. Ein Selbstbild [No problems and very busy: the first adolescent generation of the new century. A self-image]. Opladen, Germany: Leske + Budrich.

\section{Biographical Notes}

Markus P. Neuenschwander, Dr. phil. is Professor for Educational Psychology, chair of the research center Learning and Socialization, Institute for Educational Research and Development at the School for Teacher Education, University of Applied Sciences and Arts Northwestern Switzerland and at the University of Basel. His research interests focus on educational trajectories and school to work transition, teacher beliefs and student self-regulation in school.

Jan Hofmann, M.Sc., is a Junior Researcher and Ph.D. student at the Center for Learning and Socialization, Institute for Educational Research and Development at the School for Teacher Education, University of Applied Sciences and Arts Northwestern Switzerland. His research interests focus on choice actions in the career decision making process.

Andreas Jüttler, M.Sc., is a doctoral student at the chair of Business and Economics Education, Department of Economics, University of Konstanz, Germany. His research interests focus on economic competencies and school-to-work transition.

Stephan Schumann, Dr. phil., is full professor of Business and Economics Education at the Department of Economics, University of Konstanz, Germany. His research interests focus on teaching and learning, economic competencies and school-to-work transition. 